\title{
A Review on Halal Tourism: an Analysis on the Parameters
}

\author{
1* Rahmad Hakim, ${ }^{2}$ Muslikhati \\ ${ }^{1,2}$ Fakultas Agama Islam, Universitas Muhammadiyah Malang, Indonesia \\ *Email korenpondensi: rahmadhakim@umm.ac.id
}

\begin{abstract}
Halal has become a global issue today, not least in Indonesia. At the state level, Indonesia is planned to become the world halal center. This is clearly seen by the Ministry of Tourism trying to increase the number of tourists visiting Indonesia, especially visiting halal tourist destinations. Some regions are trying to compete to become areas that are friendly to halal tourism, including Lombok, Aceh and finally Malang City. Regarding the halal tourism trend, it is important to know about the concepts and parameters used in implementing halal tourism. This study aims to conduct an in-depth analysis of the concept of halal tourism and several parameters that are used as standard for halal tourism destination. The method of data collection uses documentary methods based on a review of both primary and secondary literature. The results of this study are that the concept of halal tourism can be classified into two importance aspects; first, the act of obedience, which described as a way to appreciate the greatness of God's creation. Second, the act of fulfilling an economic demand. While the parameters of halal tourism have to meet material and spiritual criteria, such as the activities have to meet shariah regulation which avoid syirk, disobedience, tabdzir or israf, and falsehood. On the other hand, the availability of services and infrastructure which meet the Muslim tourist criteria.
\end{abstract}

Keywords: Halal, Tourism, Tourist, Shariah

Saran sitasi: Hakim, R., \& Muslikhati. (2019). A Review on Halal Tourism: an Analysis on the Parameters. Jurnal Ilmiah Ekonomi Islam, 5(03), 166-172. doi: http://dx.doi.org/10.29040/jiei.v5i3.555

DOI: $\underline{\text { http://dx.doi.org/10.29040/jiei.v5i3.555 }}$

\section{Introduction}

The development of the tourism industry has experienced potential growth in recent decades. The world market for the Muslim tourism industry is estimated to be worth US \$ 151 billion in 2015. The Muslim tourism market is also projected continue to increase up to US \$ 243 billion in 2021. The Muslim tourism market also has second place in the category of the country's biggest tourist source. At least there are six largest expenditure countries for Muslim tourists, Which are Saudi Arabia US \$ 19.2 Billion, United Arab Emirates US \$ 15.1 Billion, Qatar US \$ 11.7 Billion, Kuwait US \$ 9 Billion,
Indonesia US \$ 9 Billion and Iran US \$ 7.2 Billion (Reuters, 2016).

The development of the tourism industry able to expand employment, and increase the community income (Hawkins \& Mann, 2007). According to Perić, Mujačević, \& Šimunić, (2010), travel and tourism sector produces 234 million jobs worldwide and contributes more than 10 percent of global GDP. According to Jaelani (2017), halal tourism industry has contributed to economic growth in Indonesia, although the world economy slows down. Therefore, an encouragement for the development of tourism products is also an important component in halal tourism needs such 
as attractive tourist attractions, Islamic arts and heritage and Islamic specialties (halal) and policies to encourage the growth of the tourism industry supported by bank financing (Battour \& Ismail, 2016) (Hakim, 2019) and also the academic program of halal industry (Hakim, 2016). Sriprasert, Chainin, \& Rahman (2014), added that the information of the halal food industry, travel agents that facilitate halal tourism and lodging that provides playgrounds, and places of worship for Muslim needs must be stated clearly to attract the number of Muslim tourism.

Related to halal in Indonesia, at least this country has two important capital; first, the population of Indonesian Muslims who are the population with the largest number of Muslims in the world, of course Indonesia has a bright potential to drive the halal industry given the large number of markets. The percentage of Muslims in Indonesia reaches 12.7 percent of the world population. Overall, it is reported that at least 88.1 percent of the total 205 million population of Indonesia is Muslim (Hakim, 2018). The size of the Muslim population in Indonesia outperformed several other Muslim countries, such as: Pakistan, India, Bangladesh, Egypt, Iran, Turkey and other Muslim countries (Diamant, 2019). With this large size, Indonesia is a potential market for various producers of halal goods and services, estimating the world Muslim consumer market to reach 2.7 trillion USD (Sapta Nirwandar, 2015). In general, Muslim consumers have a positive attitude towards halal products even though there is a disparity in the level of religiosity, this is an opportunity for the halal industry in Indonesia given the high level of consumption of Muslim consumers in Indonesia (Nirwandar, 2015).

\section{Reserch Method}

Regarding the halal tourism as the trending topic, it is important to know about the concepts and parameters used in implementing halal tourism for halal tourism destination. This study aims to conduct an in-depth analysis of the concept of halal tourism and several parameters that are used as standard for halal tourism destination. The method of data collection uses documentary methods based on a review of both primary and secondary literature. The results of this study aim to find out some concepts and parameters used in implementing halal tourism. The research benefit from theoretical aspect is to describe some concepts and parameters of halal tourism which issued from involved institutions and scholars. While in terms of practical aspect this research will contribute to the advance of knowledge and awareness of stakeholders of halal tourism to enhance their service and product.

The approach of this research is qualitative. This study aims to solve problems that exist in the present, on the other hand this research seeks to tell, analyze, and classify investigations (Surachmad, 1985). And conclusions from this study are not numbers. This type of research is a literature study; that is to do in-depth study of sources relevant to halal, both primary sources come from books and journals as well as secondary sources in the form of clippings of newspapers, magazines and online media news. The method used in the process of collecting data is the documentary method, which is to review documents related to the object of research, including: text, photos, stories, pictures of facts and others (Raco, 2003). Data analysis in this study uses content data analysis (content data analysis) (Bungin, 2003); namely data analysis that begins with finding certain symbols; in this case is conducting an inventory of texts that are relevant to the topic of research related to halal. The next is to make predictions or analyzes related to the classified data.

\section{Result and Analysis}

\subsection{The Halal Parameters}

Halal is a tour that is in accordance with the values of halal tourists. It aims to obtain various facilities that support Muslim tourists' worship and the avoidance of various products and 
services that are prohibited or forbidden for Muslim tourists. Some opinions state that the difference between sharia hotels and halal hotels is the determination given to the facilities offered. If sharia hotels emphasize sharia aspects, such as the necessity of Muslim tourists who want to stay at a hotel is a married couple. While the halal hotel emphasizes the aspect of fulfillment of worship facilities such as worship facilities. At least there are several parameters that have been put forward by both government and nongovernment institutions, as well as individuals from research results. Are as follows:

\subsection{The Ministry of Tourism of Indonesia}

Halal tourism destinations according to the Ministry of Tourism of Indonesia must at least meet three criteria, namely (Adinda Pryanka, Zahrotul Oktaviany, 2018; Novita Intan, 2019): first, amenity, that is, the parameters related to the availability of hotels or halal lodging places, as well as other facilities and infrastructure. Second, attractions, namely the availability of halal supporting facilities such as; the existence of halal tourist destinations, halal culinary, worship facilities and infrastructure, and the number of tourist visits. Regarding this, the Ministry of Tourism has been holding the Indonesian Muslim Travel Index (IMTI), an adaptation index of the Global Muslim Travel Index (GMTI) issued by MastercardCrescentRating (2019). Third, accessibility, namely the availability of access, both transportation, information and supporting infrastructure. Included in this case, the efforts of the relevant Regional Government and stakeholders to carry out promotion and socialization regarding halal tourism in the relevant regions.

\subsection{Fatwa of National Shariah Board- Indonesian Ulema Council (DSN-MUI)}

According to fatwa of DSN-MUI, it is stated that, sharia tourism is a travel activity carried out by a person or group of people by visiting certain places for recreational purposes, personal development, or studying the uniqueness of tourist attractions visited in the interim period; which is in accordance with sharia principles (DNS-MUI, 2016). Furthermore, sharia tourism activities must be avoided from two important elements, namely: first, syirk, disobedience, tabdzir or israf, and falsehood. Second, creating benefits and benefits both materially and spiritually. The parameters for implementing sharia tourism are as follows (DSN-MUI, 2016): (1) avoid syirk, disobedience, tabdzir or israf, and falsehood, (2) create benefits and benefits both materially and spiritually. In addition, (3) there are ijarah transactions and wakalah bil ujrah between parties in halal tourism, such as: tourists, sharia travel agents, tourism entrepreneurs, sharia hotel providers, sharia tour guides and therapists.

Meanwhile, the parameters related to sharia hotel providers include: (1) may not provide facilities for access to pornography and immoral acts, (2) may not provide entertainment facilities that lead to polytheism, immorality, pornography and or immoral acts, (3) availability of DSMMUI's halal certificates relating to food and beverages provided by sharia hotels, (4) the availability of adequate facilities, equipment and facilities for the implementation of worship, including purification facilities, (5) managers and hotel employees or employees must wear clothing that is in accordance with sharia, (6) the existence of guidelines and or guidelines regarding hotel service procedures to ensure the implementation of hotel services in accordance with sharia principles, (7) to synergize with Islamic Financial Institutions in conducting services.

Tourist destinations must have, the following points: (1) worship facilities are feasible, easy to reach and meet sharia requirements, (2) halal food and beverages guaranteed by DSM-MUI's Halal Certificates, (3) destinations must avoid (a) syirk and khurafat, (b) immorality, adultery, pornography, porno-action, liquor, drugs and gambling, (c) art and cultural performances and attractions that conflict with sharia principles. 
In addition, spa services, saunas and massages must fulfill the following conditions: (1) using halal and unclean ingredients guaranteed by DSM-MUI's Halal certificate, (2) avoiding pornography and pornography, (3) safeguarding the honor of tourists, (4) male therapists may only do spas, saunas, and massages for male tourists; and female therapists can only do spas, saunas, and massages for female tourists, (5) there are facilities that make it easy to worship.

\subsection{Global Muslim Traveler Index (GMTI)}

On the other hand, a parameter released issued by Global Muslim Traveler Index (GMTI), some of them are (MastercardCrescentRating, 2019): 1) Existence of access (access), 2) existence of communication (communication), 3) environmental conditions, 4) the services. The four criteria can be abbreviated with ACES. The indicator of access including visa requirements, connectivity and transport infrastructure. Whereas the indicator of communication are an outreach, ease of communication, and digital presence. In an environment indicator are safety, faith restrictions, visitor arrivals, and enabling climate. While the services can be indicate as follows, core needs (halal food and prayer facilities), core services (hotels and airports), and unique experiences.

\subsection{Cape Town Tourism (CTT) and Crescent Rating (2018)}

According to Cape Town Tourism (CTT) and Crescent Rating (2018), some parameters released by the Cape Town Company in fulfilling halal tourism are as follows:

1) The existence of airports (airports), terminals and ports that have Muslim tourist-friendly facilities, including: the existence of restaurants, houses of worship, worship facilities, information staff that serve the needs of Muslim tourists,

2) Availability of hotels or resorts that provide halal facilities,
3) Availability of restaurants or halal food outlets and the separation of toilets between men and women,

4) Availability of halal shopping places with the availability of facilities that are friendly to Muslim tourists,

5) The existence of a supporting information center along with the guidelines provided adjusts the needs of Muslim tourists, such as: maps related to mosques, halal outlets, halal restaurants, and tourist destinations for Muslim tourists,

6) The existence of tourism agents and assistance of Muslim tourist friendly tours.

7) Availability of parks (green open spaces) or halal tourist friendly tourist destinations,

8) Availability of event conference venues,

9) Availability of competition venues for sports, accompanied by supporting facilities, such as food outlets, prayer rooms and so on,

Availability of spa services and therapeutic friendly Muslim tourists.

\subsection{The Concept of Halal City}

Another parameter is the concept of halal city suggested by Tresna M, Pradana, Firgiawan, \& Prasyatiani (2017), must at least meet the following four (4) criteria:

1) Availability of halal accommodation, restaurants and hotels,

2) Availability of halal markets, starting from goods sold, the transaction process must meet halal criteria (without any elements of gharar, maysir and usury,

3) Availability of travel packages; namely the package of travel offers to various halal tourist destinations friendly to Muslim tourists, for example a warning to perform worship along with supporting facilities,

4) The existence of halal regulations; the existence of regulations has an important function as a supporting regulation so that the concept of halal city can run and apply in accordance with the guidelines of Islamic law and create comfort and security in accordance with Islamic guidelines and applicable laws. 


\subsection{Parameter of Daulah Madinah}

According to Parameter of Daulah Madinah, halal city is a city where Islamic values are applied by referring to the State of Medina (Saputra, 2019). Some parameters used are as follows;

1) Quality of self and behavior of residents in accordance with Islamic law,
2) City life system that places Islamic law and authority as a guideline for people's lives, for continuous improvement to achieve justice,

3) The behavior of the community achieves the quality of just and individual life in communal society by devoting themselves to Allah.

Table 1.

The Parameters of Halal Tourism

\begin{tabular}{|c|c|c|}
\hline No & Opinion & Parameters \\
\hline 1 & $\begin{array}{l}\text { The Ministry of } \\
\text { Tourism of } \\
\text { Indonesia }\end{array}$ & $\begin{array}{l}\text { 1) An amenity, which is related to the availability of hotels or halal } \\
\text { lodging places, as well as other facilities and infrastructure. } \\
\text { 2) An attractions refers to the availability of halal supporting } \\
\text { facilities such as of halal tourist destinations, halal culinary, } \\
\text { worship facilities and infrastructure. } \\
\text { 3) An accessibility, refers to the availability of transportation, } \\
\text { information and supporting infrastructure. }\end{array}$ \\
\hline 2 & DSN-MUI & $\begin{array}{l}\text { 1) To avoid syirk, disobedience, tabdzir or israf, and falsehood, } \\
\text { 2) To create benefits and benefits both materially and spiritually. } \\
\text { 3) There are ijarah transactions and wakalah bil ujrah between } \\
\text { parties in halal tourism, such as: tourists, sharia travel agents, } \\
\text { tourism entrepreneurs, sharia hotel providers, sharia tour guides } \\
\text { and therapists. }\end{array}$ \\
\hline 3 & $\begin{array}{l}\text { Global Muslim } \\
\text { Traveler Index } \\
\text { (GMTI) }\end{array}$ & $\begin{array}{l}\text { 1) An existence of access (access), } \\
\text { 2) An existence of communication } \\
\text { 3) An environmental conditions, } \\
\text { 4) An existence services. }\end{array}$ \\
\hline 4 & $\begin{array}{l}\text { Cape Town Tourism } \\
\text { (CTT) and Crescent } \\
\text { Rating }\end{array}$ & $\begin{array}{l}\text { 1) The existence of airports (airports), terminals and ports that have } \\
\text { Muslim tourist-friendly facilities, including: the existence of } \\
\text { restaurants, houses of worship, worship facilities, information } \\
\text { staff that serve the needs of Muslim tourists, } \\
\text { 2) Availability of hotels or resorts that provide halal facilities, } \\
\text { 3) Availability of restaurants or halal food outlets and the separation } \\
\text { of toilets between men and women, } \\
\text { 4) Availability of halal shopping places with the availability of } \\
\text { facilities that are friendly to Muslim tourists, } \\
\text { 5) The existence of a supporting information center along with the } \\
\text { guidelines provided adjusts the needs of Muslim tourists, such as: } \\
\text { maps related to mosques, halal outlets, halal restaurants, and } \\
\text { tourist destinations for Muslim tourists, } \\
\text { 6) The existence of tourism agents and assistance of Muslim tourist } \\
\text { friendly tours. } \\
\text { 7) Availability of parks (green open spaces) or halal tourist friendly } \\
\text { tourist destinations, } \\
\text { 8) Availability of event conference venues, } \\
\text { 9) Availability of competition venues for sports, accompanied by } \\
\text { supporting facilities, such as food outlets, prayer rooms and so on, } \\
\text { 10) Availability of spa services and therapeutic friendly Muslim } \\
\text { tourists. }\end{array}$ \\
\hline
\end{tabular}




\begin{tabular}{|c|c|c|}
\hline 5 & $\begin{array}{l}\text { Tresna M, Pradana, } \\
\text { Firgiawan, \& } \\
\text { Prasyatiani (2017) }\end{array}$ & $\begin{array}{l}\text { 1) Availability of halal accommodation, restaurants and hotels, } \\
\text { 2) Availability of halal markets, starting from goods sold, the } \\
\text { transaction process must meet halal criteria (without any elements } \\
\text { of gharar, maysir and usury, } \\
\text { 3) Availability of travel packages; namely the package of travel } \\
\text { offers to various halal tourist destinations friendly to Muslim } \\
\text { tourists, for example a warning to perform worship along with } \\
\text { supporting facilities, } \\
\text { 4) The existence of halal regulations; the existence of regulations } \\
\text { has an important function as a supporting regulation so that the } \\
\text { concept of halal city can run and apply in accordance with the } \\
\text { guidelines of Islamic law and create comfort and security in } \\
\text { accordance with Islamic guidelines and applicable laws. }\end{array}$ \\
\hline 6 & $\begin{array}{l}\text { Parameter of Daulah } \\
\text { Madinah (Saputra, } \\
\text { 2019) }\end{array}$ & $\begin{array}{l}\text { 1) Quality of self and behavior of residents in accordance with } \\
\text { Islamic law, } \\
\text { 2) City life system that places Islamic law and authority as a } \\
\text { guideline for people's lives, } \\
\text { 3) The behavior of the community achieves the quality of just and } \\
\text { individual life in communal society by devoting themselves to } \\
\text { Allah }\end{array}$ \\
\hline
\end{tabular}

\section{Kesimpulan}

Based on the discussion above, it can be concluded that halal tourism is has become a global issue today. To address the some concepts and parameters of halal tourism which issued from involved institutions and scholars and to the advance of knowledge and awareness of stakeholders of halal tourism to enhance their service and product, this research is importance. The concept of halal tourism can be classified into two importance aspects; first, the act of obedience, which described as a way to appreciate the greatness of God's creation. Second, the act of fulfilling an economic demand, which described as a travel activity carried out by a person or group of people by visiting certain places for recreational purposes, personal development or learning the unique tourist attractions within a temporary period and in accordance with sharia principles. The parameters of halal tourism had been issued by several institutions and scholars, such The Ministry of Tourism of Indonesia, DSN-MUI, Global Muslim Traveler Index (GMTI), Cape Town Tourism (CTT) and Crescent Rating, Tresna M, Pradana, Firgiawan, \& Prasyatiani, and Saputra. Generally, the parameters of halal tourisme have to meet material and spiritual criteria, such as the activities have to meet shariah regulation which avoid syirk, disobedience, tabdzir or israf, and falsehood. And also the availability of services and infrastructure which meet the Muslim tourist criteria.

\section{Daftar Pustaka}

Adinda Pryanka, Zahrotul Oktaviany, M. N. (2018). Tiga Destinasi Wisata Halal Utama Indonesia. Republika, 20.

Battour, M., \& Ismail, M. N. (2016). Halal tourism: Concepts, practises, challenges and future. Tourism Management Perspectives, 19 , 150-154.

https://doi.org/10.1016/j.tmp.2015.12.008

Bungin, Burhan. (2003). Analisis Data Penelitian Kualitatif. Jakarta: PT Raja Grafindo.

Cape Town Tourism (CTT) and Crescent Rating. (2018). Cape Tow n Halal Tourism Basic Guidelines and Glossary, (February). Retrieved from http://www.capetown.travel/wpcontent/uploads/2018/04/CTT-HalalTourism-Guidelines-and-Glossary.pdf

Din, K. H. (1989). Islam \& Tourism. Annals of Tourism Research, 542-563. 
Duman, T. (2011). Value of Islamic Tourism Offering: Perspectives from the Turkish Experience Value of Islamic Tourism Offering: Perspectives from the Turkish Experience Paper presented at, World Islamic Tourism Forum ( WITF 2011 ) Seri Pacific Hotel , Kuala Lumpur Glob, (December).

Hakim, Rahmad. "Urgensi Program Studi Produk Halal di Indonesia”. Opini Harian Malangpost, 29, September, 2016.

Hakim, Rahmad. "Quo Vadis Industri Halal”.

Opini Harian Republika, 17 Desember 2018. Hakim, Rahmad. "Menanti Regulasi Pariwisata Halal”. Opini Harian Malangpost, 26 Juni 2019.

Hawkins, D. E., \& Mann, S. (2007). The world bank's role in tourism development. Annals of Tourism Research, 34(2), 348-363. https://doi.org/10.1016/j.annals.2006.10.004 Indonesia, D. S. N.-M. U. Fatwa Dewan Syariah Nasional-Majelis Ulaman Indonesia, No.108/DSN-MUI/X/2016, Pub. L. No. 108/DSN-MUI/X/2016, 1 (2016). Indonesia: DSN-MUI.

Jaelani, A. (2017). Halal Tourism Industry in Indonesia: Potential and Prospects. Ssrn, (July). https://doi.org/10.2139/ssrn.2899864

Jeff Diamant. (2019). The countries with the 10 largest Christian populations and the 10 largest Muslim populations.

Kamarudin, L. M., \& Nizam, H. (2012). Islamic Tourism: The Impacts To Malaysia's Tourism Industry. International Conference on Tourism Development, (February), 397. https://doi.org/FML1020

[pii]ไr10.1111/j.1574-6968.2007.01020.x

Laderlah, S. A., Rahman, S. A., Awang, K., \& Man, Y. C. (2011). A study on islamic tourism: a Malaysian Experience. 2nd International Conferences of Humanities and Social Sciences, 17, 184-189.
Mastercard-CrescentRating. (2019). Global Muslim Travel Index 2019. Retrieved from https://www.crescentrating.com/download/th ankyou.html?file $=$ X7UrOM8Y_GMITI-

Report-2018-web-version\%281\%29.pdf

Novita Intan, M. N. (2019). Wisata Halal

Terkendala Amenitas. Republika, p. 15.

Raco J.R, (2003). Metode Penelitian Kualitatif Jenis Karakteristik dan Keunggulannya. Yogyakarta: Pustaka Pelajar.

Reuters, T. (2016). State of the Global Islamic Economy Report 2016/2017. USA.

Sapta Nirwandar. (2015). Halal Lifestyle, Trend Global, \& Peluang Bisnis.

Saputra, A. (2019). Kota Islam: Tinjauan Maknawi. ISLAMIA: Jurnal Pemikiran Islam Republika, Republika, p. 19.

SESRTCIC. (2006). International tourism in OIC member countries: Prospects and challenges. Journal of Economic Cooperation, 27(2), 101-138.

Sriprasert, P., Chainin, O., \& Rahman, H. A. (2014). Understanding Behavior and Needs of Halal Tourism in Andaman Gulf of Thailand: A Case of Asian Muslim. Journal of Advanced Management Science, 2(3), 216-219.

https://doi.org/10.12720/joams.2.3.216-219

Surakhmad, Winarno. (1985). Pengantar Penelitian Ilmiah Dasar Metode Teknik. Bandung: Transito.

Tresna M, O., Pradana, A. ., Firgiawan, R., \& Prasyatiani, T. (2017). Halal Town as Innovation for Tourism. International Journal of Management and Applied Science, 3(2), 55-58. Retrieved from http://ijmas.iraj.in/author.php?author=Tia Prasyatiani. 